Original Article

\title{
ANALYSIS OF THE OPTIMAL NUMBER OF STAFF NEEDED USING WORKLOAD INDICATOR OF STAFFING NEEDED (WISN) METHOD IN LABORATORY UNIT OF PUBLIC HOSPITAL ANUTAPURA PALU
}

\author{
Muh. Ryman Napirah ${ }^{1 *}$, Andi Okki Sulistiani ${ }^{1}$ \\ ${ }^{1}$ Health Administration and Policy Department, Public Health Study Program, \\ Faculty of Medical and Health Science, Tadulako University, Indonesia
}

Accepted: 10 September 2015

*Correspondence:

Muh. Ryman Napirah

E-mail: ryman_smart@yahoo.com

\begin{abstract}
Background: The amount of labor in the laboratory unit hospital of Anutapura Palu workforce was 30 people, but there were still problems in terms of inspection of samples that only consisted of some people in a kind of examination while in terms of inspection of the sample was in need of power because the large number of visits from patients who require to carry out an examination of sample. One of manpower planning method is Workload Indicator Of Staffing Needed (WISN) that calculated the optimal amount based on workload of employees.

Objective: This study aimed at finding out of the optimal number of staff needed in The laboratory unit at RSU Anutapura using WISN method.

Methods: This study was a quantitative study with descriptive approach. Data were collected using work sampling method, observation, and document review.

Results: It showed that using productive time of the activities time total was $88,51 \%$ and using productive time of working hours was 114,240 minutes per year, workload standard is 5817.32 per year and the loose standard is 0,4 per year.

Conclusion: Based on the analysis of the optimal number of staff needed using WISN method, it can be concluded that the laboratory unit still needs 8 people, and for manpower planning, things that need to consider are qualification and competence to get a good quality of labor.
\end{abstract}

Keywords: Staff needed, WISN method, Planning human resources

\section{INTRODUCTION}

Human Resources (HR) are the most important asset that should be owned by the organization or company. Human resources are people who design and produce goods or services; oversee quality, product marketing, allocating financial resources, as well as to formulate strategies and objectives throughout the organization. Organization without expertise or competence staffs is impossible to achieve its objectives. ${ }^{1}$ Human resources planning is an estimating process the amount of human resources based on place, skills, and behaviors needed to deliver health services. Health workers as Human Resources (HR) in running health services in hospitals are an important resource and needed to achieve optimum performance. ${ }^{2}$ 
One of methods for calculating the amount of power based on need is Workload Indicator of Staffing Needed (WISN). This method is recommended by the Ministry of Health through the Minister of Health Decree No. 81 / Menkes / I / 2004. Compared with other methods, according to the Ministry of Health, WISN method is easy to operate, easy to use and technically easy to implement in a comprehensive and realistic result. Usually this method is used to calculate the amount of the needs of each category of health workers is needed. ${ }^{3}$ Hospitals implement health care through medical services and non-medical services. The medical services include treatment, care and support facilities for the health of others and the non-medical services are administration services starting from the registration until the payment section or cashier. One unit in the hospital plays a major role in supporting operational activities are a laboratory. Hospital laboratory is a hospital unit, which its existence cannot be separated from the hospital because it is a supporting health care effort.

A Laboratory Unit of RSU Anutapura Palu is one of the medical support units at the hospital, which is a government hospital education type B. This unit is a functional unit and responsible to the director of medical support through the head section, with the duties and functions for supporting the hospital operations, especially in terms of testing the causes of disease. Due to the role of the laboratory in supporting the operations of the hospital, the plan needs to be in accordance with the needs of human resources, both in terms of type and amount. The calculation of the exact needs of the number of employees in the laboratory RSU Anutapura Palu, then part of the laboratory unit of RSU Anutapura is expected to optimize the work that can support labor productivity General Hospital Anutapura Palu. Due to the increase in labor productivity, especially in laboratory units, it is expected to support the increased diagnosis as effectively as possible with optimum results.

Tasks division and activities carried out by workers at the Laboratory of RSU Anutapura unit divided into several sections according to a predetermined working time and in accordance with the number of patients being examined. Working time of employee in the laboratory unit is 24 hours with three shifts a day for 7 days work in a week. Due to the long working time, the workload of the employees in the unit Laboratory is higher, based on preliminary studies had been conducted obtained that workload experienced by employees in the unit Laboratory in RSU Anutapura is still high due to the number of employees who are still less in number. As a provider of health care services as well as technical working 8-24 hours a day for health care activities in the laboratory requires the pattern shift and night watch. Work patterns change may cause increased fatigue. Whereas the standard leeway in laboratory units tend to have a little more leeway than the other units because of the continuous work done also no days off for employees also further reduces the standard clearances of employees.

\section{METHODS}

This study was a quantitative method with a descriptive approach. Descriptive approach aims to create a description, picture of systematic, factual and accurate information on the facts, nature and the relationship between the phenomena investigated. This research was conducted in the laboratory unit of the

(C) Public Health of Indonesia - YCAB Publisher, Volume 1, Issue 1, July-September 2015 | 2 
General Hospital (RSU) Anutapura Palu from April to May 2015. The population was laboratory employees included 30 people, based on inclusion and exclusion criteria. Samples in this research were an employee who worked in the laboratory, which total of 23 people.

Collecting data using two data type, were primary and secondary data. The primary data were collected by a questionnaire to describe the perception of employees and observation sheets to obtain observations and analysis of the workers needs in the unit laboratory. The secondary data obtained from the literature searching related to this study and laboratory examinations data, employee absenteeism and job descriptions of employees. Data processed using univariate analysis.

\section{RESULTS}

\section{Tasks and Activities}

As the results, the univariate analysis of respondent's perception showed in Table 1 . It is indicated that 22 respondents $(95.6 \%)$ gave a good perception of the tasks and activities, one respondent $(4.3 \%)$ gave unfavorable perception of the tasks and activities in the laboratory unit.

Tabel 1. The Univariate Analysis of the Perception of Respondents in RSU Anutapura Palu

\begin{tabular}{|l|l|l|}
\hline Respondent Perception & Frequency & Percentage (\%) \\
\hline Good & 22 & $95.6 \%$ \\
\hline Not good & 1 & $4.3 \%$ \\
\hline Working Time & & \\
\hline Effective & 21 & $91.3 \%$ \\
\hline Less effective & 2 & $8.7 \%$ \\
\hline Standard Workload & & \\
\hline Excess & 16 & $69.6 \%$ \\
\hline Not excess & 7 & $30.4 \%$ \\
\hline Standard Allowance & & \\
\hline Lax & 21 & $91.3 \%$ \\
\hline Less lax & 2 & $8.7 \%$ \\
\hline Power Requirements & & \\
\hline Need & 20 & $87 \%$ \\
\hline Not need & 3 & $13 \%$ \\
\hline
\end{tabular}

While Table 2 illustrates activity and the time spent by employees in the laboratory unit of RSU Anutapura Palu during observation with the process table. Activities conducted divided into productive activity, non-productive activities and private events. It can be seen that the productive activities performed by employees at the highest laboratory unit is done in the morning $(91.69 \%)$ and the lowest was done at night $(83.69 \%)$, this is due to the number of patients. For nonproductive activities performed by employees at the highest laboratory units done at night $(10.02 \%)$ and the lowest was done in the morning $(5.8 \%)$. This is because at night few patients who examined the samples in the laboratory, because the employees have more time to carry out non-productive activities. And for personal activities performed by employees at the highest laboratory units done at night $(6.26 \%)$ and the lowest in the morning $(2.47 \%)$, similar to the nonproductive activities were also high at night time because the number of patients handled in a laboratory unit is less than the morning and afternoon, because the 
employees have more time to do personal activities.

Tabel 2. Overview Usage Working Time To Type of Activity During the 7 days of work at the Laboratory Unit RSU Anutapura Palu

\begin{tabular}{|c|c|c|c|c|c|c|c|}
\hline \multirow{3}{*}{ NO } & \multirow{3}{*}{ Activities } & \multicolumn{6}{|c|}{ Working days } \\
\hline & & \multicolumn{2}{|c|}{ Morning } & \multicolumn{2}{|c|}{ Afternoon } & \multicolumn{2}{|c|}{ Night } \\
\hline & & f & $\%$ & $\mathbf{f}$ & $\%$ & $\mathbf{F}$ & $\%$ \\
\hline \multicolumn{8}{|c|}{ Productive Activities } \\
\hline 1 & Taking sampel & 7140 & 16.9 & 5270 & 16.63 & 2720 & 16.24 \\
\hline 2 & Check sampel & 13745 & 32.54 & 10225 & 32.27 & 4525 & 27.01 \\
\hline 3 & Perform Validation & 3570 & 8.45 & 2615 & 8.25 & 1355 & 8.09 \\
\hline 4 & Type the result & 2142 & 5.07 & 1569 & 4.95 & 813 & 4.85 \\
\hline 5 & Data entry & 7140 & 16.9 & 5230 & 16.5 & 2710 & 16.18 \\
\hline 6 & $\begin{array}{l}\text { To deliver the results of the } \\
\text { examination room }\end{array}$ & 4998 & 11.83 & 3661 & 11.55 & 1897 & 11.32 \\
\hline & Subtotal & 38735 & 91.69 & 28570 & 90.15 & 14020 & 83.69 \\
\hline \multicolumn{8}{|c|}{ Non Productive Activities } \\
\hline 1 & Discuss & 1155 & 2.73 & 980 & 3.09 & 805 & 4.8 \\
\hline 2 & Watching TV & 245 & 0.58 & 280 & 0.88 & 665 & 3.97 \\
\hline \multirow[t]{2}{*}{3} & Oter Non Productive Activities & 1050 & 2.49 & 630 & 1.98 & 210 & 1.25 \\
\hline & Subtotal & 2450 & 5.8 & 1890 & 5.95 & 1680 & 10.02 \\
\hline \multicolumn{8}{|c|}{ Private Activities } \\
\hline 1 & Eat/drink & 560 & 1.32 & 455 & 1.44 & 280 & 1.67 \\
\hline 2 & Pray & 140 & 0.33 & 280 & 0.88 & 140 & 0.83 \\
\hline \multirow[t]{3}{*}{3} & Sellular communication & 350 & 0.82 & 490 & 1.55 & 630 & 3.76 \\
\hline & Subtotal & 1050 & 2.47 & 1225 & 3.87 & 1050 & 6.26 \\
\hline & Total & 42235 & 100 & 31685 & 100 & 16750 & 100 \\
\hline
\end{tabular}

\section{Working Time}

As the results of the univariate analysis of the perception of respondents in Table 1 is known that that 21 respondents $(91.3 \%)$ provide effective perception regarding working time and 2 respondents $(8.7 \%)$ give less effective perception regarding working time. This is because the working time in the laboratory unit that is still in the standard 6-8 hours per day. Although the whole working time is 24 hours, but it is able to overcome the division of work shifts so that the working time is not too burden some employees. In Table 3 , it is known that the working time available to employees in the unit laboratory during the year is $114,240-\mathrm{min} /$ year.

\section{Standard Workload}

The results of the univariate analysis of the perception of respondents in table 1 showed that 16 respondents $(69.6 \%)$ give the perception of excess of the standard workload and 7 respondents $(30.4 \%)$ give the perception were not the excess of the standard workload. Table 4 showed that the existing workload standards in the laboratory unit amounted to 5817.32 minutes per year. 
Tabel 3. Working Time Over Time Period One Year in Laboratory Unit RSU Anutapura Palu

\begin{tabular}{|l|l|l|l|}
\hline Code & Factors & Total & Description \\
\hline A & Working days & 365 & Day/Year \\
\hline B & Annual Leave & 90 & Day/Year \\
\hline C & $\begin{array}{l}\text { Education and } \\
\text { training }\end{array}$ & 7 & Day/Year \\
\hline D & $\begin{array}{l}\text { National } \\
\text { holiday }\end{array}$ & 0 & Day/Year \\
\hline E & Work absences & 30 & Day/Year \\
\hline F & Working time & 8 & Hour/Year \\
\hline
\end{tabular}

\section{Standard Allowance}

As the results of the univariate analysis of the perception of respondents in Table 1 showed that 21 respondents $(91.3 \%)$ give the perception of lax standards regarding clearances and 2 respondents $(8.7 \%)$ gives the perception of less lax of standards clearances. In Table 5 showed that the standard leniency in the laboratory unit amounted to 0.4 minutes or $40 \%$ per year.

Tabel 4. Workload standards in laboratory Unit RSU Anutapura Palu

\begin{tabular}{|l|l|l|l|}
\hline NO & Tasks and Activities & On average Time & Standard Workload \\
\hline 1 & Taking samples & 150 & 761.6 \\
\hline 2 & Check sample & 235 & 486.12 \\
\hline 3 & Perform Validation & 60 & 1904 \\
\hline 4 & Type the result & 200 & 571.2 \\
\hline 5 & Data entry & 100 & 1142.4 \\
\hline 6 & $\begin{array}{l}\text { To deliver the results of the } \\
\text { examination room }\end{array}$ & 120 & 952 \\
\hline Total of Working Load Standard & $\mathbf{5 8 1 7 . 3 2}$ \\
\hline
\end{tabular}

Tabel 5. Time Allowance in Laboratory Unit RSU Anutapura Palu

\begin{tabular}{|l|l|l|l|}
\hline NO & Allowance Factor & On average Time & $\begin{array}{l}\text { Standard } \\
\text { Allowance }\end{array}$ \\
\hline 1 & Doing Preparation Sampling & 30 minute/day & 0,096 \\
\hline 2 & Disposing of Waste & 20 minute/day & 0,064 \\
\hline 3 & discuss & 60 minute/day & 0,191 \\
\hline 4 & Doing Preparation Needs Consumables & 15 minute/day & 0,048 \\
\hline \multicolumn{2}{|l}{ Total Standar Allowance } & $\mathbf{0 , 4}$ \\
\hline
\end{tabular}

\section{Power Requirements}

Results of the univariate analysis of the perception of respondents in table 1 showed that 20 respondents $(87 \%)$ give the perception takes on manpower needs and 3 respondents $(13 \%)$ give the perception does not need the power requirements.

\section{DISCUSSION}

\section{Tasks and Activities}

Tasks and work should be clearly defined for each position, so that workers know the duties and responsibilities that must be done. ${ }^{4}$
Every human has a job description that they should use as a guide in performing their duties. Job description is a summary of the activities that are important and include duties and responsibilities. In other words, the job description describes what should be done. Job descriptions are the details of the work containing comprehensive information about the duties and obligations, responsibilities, and conditions required when the work is done as well as guidelines, guidance, and direction of action for labor to carry out the work 
according to the duties and responsibilities. ${ }^{5}$

In the description of the tasks and activities contained details of events consisting of productive activity, nonproductive activities and private events. In Table 2 showed that the use of working time for productive activities amounted to $88.6 \%$, then the use of work time by employees of the laboratory unit can be said to have been productive for optimum productive work time to $80 \%{ }^{6}$

Productive activities performed by employees at the highest laboratory unit were done in the morning $(91.69 \%)$ and the lowest was done at night $(83.69 \%)$, this was because the large number of patient samples to be examined in the morning than any other time.

For non-productive activities performed by employees at the highest laboratory units done at night $(10.02 \%)$ and the lowest was done in the morning $(5.8 \%)$. This was because at night few patients who examined the samples in the laboratory, because the employees have more time to carry out non-productive activities.

Personal activities performed by employees at the highest laboratory units done at night $(6.26 \%)$ and the lowest in the morning $(2.47 \%)$, similar to the nonproductive activities were also high at night time because the number of patients treated in Laboratory units less than the morning and afternoon, because the employees have more time to do personal activities.

\section{Working Time}

Work time available to employees at the unit lab is working time must be met by an employee in an activity principally in the laboratory unit RSU Anutapura Palu for a year.
As for the time working in the laboratory unit RSU Anutapura Palu divided into 3 shifts to the working day for 7 weekdays. The division of labor shift is intended to reduce the fatigue of the employees as well as to divide the number of employees by the number of patients per day. Especially for employees assigned to work on the night shift will get off one day after he worked on the night shift. Although it should work for 7 days but based on research results, employees in the laboratory unit still feels the working time in their work units remain effective.

In Table 3, it explained about the factors that affect working time namely working days during the year that is 365 days per year, annual leave of 90 days per year, education and training followed by the employee during the 7 days per year, national holidays are not counted because the employees keep working on these days, absenteeism is 30 days per year earned by employee absenteeism in the laboratory unit and work time for 8 hours per day in the laboratory unit in order to obtain the results of total working time available in the lab for a year is 114,240 minutes / year or 1904 hours / year.

\section{Standard Workload}

Standard workload is obtained from the available work time divided by the average time used to complete main activities. As on observations made then obtained six principal activities performed by employees in the laboratory unit that activities take samples, check samples, validating the results of the examination typing, inputting data and deliver the results to the examination room. ${ }^{7}$

For the analysis workload as a process to set the number of hours people are used or needed to complete a job within a certain time, or in other words, 
workload analysis aims to determine how the number of personnel and the amount of responsibility or workload right handed to an officer. By dividing the content of the work that must be completed by the work of an average of one person, it will gain the time needed to complete the job or will obtain the number of employees needed by the number of hours worked each of these employees.

\section{Standard Allowance}

Standard spare time used to carry out other activities that are not directly related but still have benefits for employees. ${ }^{7}$ Based on the observation that manpower needs formula:
The employee still has sufficient leeway time in addition to the employee can perform personal activities. Grace can be done while awaiting the results of the sample or at certain times such as early mornings and late break.

\section{Power Requirements}

One method used to calculate HR needs based on workload is WISN method. This method is useful for calculating the energy needs of today and the future and to be able to identify how much the workload of health human resources. ${ }^{7}$ The formula to calculate the power requirements of the ideal laboratory unit is:

Formula to calculate the power equirements:

$=\frac{(\text { Main activities })+\text { SK }}{\text { SBK }}$
$=(\underline{\text { 44980 })+0,4}$

5817,32

$=7,7+0,4$

$=8$

Based on the calculation above, obtained total energy needs in a RSU Anutapura Palu laboratory unit totaled 8 staff. Obtaining energy needs in the laboratory were 8 staff aims to increase productivity in the laboratory unit. Given the number of patients who examined the samples and therefore contributes to the workload of employees who are in the laboratory unit. Therefore, any increases in the power of this unit can alleviate the existing workload. Based on these results, it can be made a human resources planning by a laboratory unit, remember to increase the productivity of labor, the need for manpower and in accordance with the existing workload in the unit.

HR needs planning is not an activity that is easy to do, as a unit should also estimate the budget in accordance with the amount of work the existing workforce. Calculation of HR needs to be using a method of calculation that is based on the actual workload undertaken by each category of health human resources in each unit of work in a health service. 


\section{CONCLUSION}

Description of the tasks and activities in the laboratory unit consists of productive activity; nonproductive activities and personal activities, implementation of employee laboratory unit have been productive. On the other hand, working time is available in the laboratory during the year was 114,240 min / year or 1904 hours / year.

The workload in the laboratory unit RSU Anutapura Palu was still high according to the perception of $69.6 \%$ employees, and each employee has a standard laboratory workload as much as 5817.32 per year. Time looseness in the laboratory unit can be quite loose and do not interfere with the activity of employees in the laboratory unit RSU Anutapura Palu. Every employee has the leeway factor of 0.4 , or about $40 \%$ per year. And the need for labor in RSU Anutapura Palu laboratory unit still requires a workforce of 8 staff.

Therefore, it is suggested that RSU Anutapura Palu needs to be able to make workforce planning need more specific to meet the human resource requiring the hospital to serve the health service, particularly laboratory unit needs to be able to perform additional work force to suppress the high number of existing workload. The unit is also able to achieve optimum performance due to insufficient workers number.

This study provided the insight of knowlegde and the result could be used as reference for those who want to conduct a study on the same or next researchers can explore beyond.

Funding: No funding sources Conflict of interest: None declared Ethical Approval: The study was approved by the institutional ethic committee

\section{REFERENCES}

1. Samsudin, Sadili. 2009. Manajemen Sumber Daya Manusia (edisi 2). Bandung. Pustaka Setia

2. Ilyas. 2011. Kinerja, Teori, Penilaian dan Pelatihan. Jakarta. BP FKUM UI.

3. Puspita. 2011. Analisis Kebutuhan Tenaga Dengan Metode WISN Di Unit Pelatihan dan Pengembangan Rumah Sakit Tebet Jakarta. UI

4. Hasibuan, S.P. Malayu. 2008. Manajemen Sumber Daya Manusia. Cetakan ketujuh, Jakarta. Penerbit PT. Bumi Aksara

5. Sastrohadiwiryo, Siswanto. 2002. Manajemen Tenaga Kerja Indonesia. Jakarta : Bumi Aksara

6. Ilyas. 2004. Perencanaan SDM Rumah Sakit : Teori, Metode dan Formula. Depok: Fakultas Kesehatan Masyarakat, UI

7. Kepmenkes. 2004. Kepmenkes Nomor 81/Menkes/I/2004.

Departemen

Kesehatan RI. Jakarta

Cite this article as: Napirah $\mathrm{RM}$, Sulistiani AO. Analysis of the Optimal Number of Staff Needed using Workload Indicator of Staffing Needed (WISN) Method in Laboratory Unit of Public Hospital Anutapura Palu. Public Health of Indonesia 2015;1:1-8. 